\title{
ANALISIS KEMAMPUAN BERPIKIR KREATIF MATEMATIS SISWA SMK PADA MATERI BARISAN DAN DERET DI KOTA PEKANBARU
}

\author{
Indira Santi ${ }^{1}$, Maimunah ${ }^{2 *}$, Yenita Roza ${ }^{3}$ \\ ${ }^{1,2,3}$ Magister Pendidikan Matematika , Universitas Riau \\ 1email: indira.santi7066@grad.unri.ac.id \\ ${ }^{2}$ email: Maimunah@lecturer.unri.ac.id \\ ${ }^{3}$ email: yenita.roza@lecturer.unri.ac.id
}

\begin{abstract}
The ability to think mathematically creative is one of the competency standards for graduate students at the vocational level. Based on the results of previous studies said that the mathematical creative thinking ability of vocational students is very low and the interview of researchers in several mathematics teachers in Pekanbaru vocational school said that Pekanbaru vocational students were accustomed to mathematical problems according to the teacher's example and it was recognized that teachers lacked daily problems. This study aims to determine the mathematical creative thinking ability of vocational students in Pekanbaru City in row and series material. This type of research is a qualitative descriptive study. The instrument used was a mathematical creative thinking ability test with 4 indicators namely fluency, flexibility, originality and elaboration. Questions in the form of a breakdown test were taken from the SMK National Exam question bank and given to 36 students of class X TKJ-2 SMKN 2 Pekanbaru. From the test results it can be concluded that the percentage of mathematical creative thinking ability of SMKN 2 students is at the ability to think creatively enough at $42 \%$. Where the fluency indicator is $56 \%$, the indicator of Authenticity (originality) is $38 \%$, the Elaboration indicator is $46 \%$ and the indicator of Flexibility is $28 \%$.
\end{abstract}

Kata Kunci : Kemampuan Berpikir kreatif Matematis, Barisan dan Deret

\section{PENDAHULUAN}

Kurikulum 2013 menyebutkan bahwa Standar Kompetensi Lulusan siswa pada jenjang SMA/SMK adalah memiliki kemampuan berpikir tingkat tinggi ( Higher Order Thinking Skill). Matematika merupakan salah satu wadah yang tepat untuk meningkatkan kemampuan berpikir tingkat tinggi. Salah satu kemampuan berpikir tingkat tinggi itu adalah kemampuan berpikir kreatif, hal ini sesuai dengan pernyataan King, Goodson, \& Rohani (Mulyaningsih \& Ratu, 2018 : 65) "Higher order thinking skills include critical, logical, reflective, metacognitive, and creative thinking". Bahwa kemampuan berpikir tingkat tinggi (Higher Order Thinking Skills) mencakup berpikir kritis, logis, kreatif, reflektif, dan metakognitif

Kemampuan berpikir kreatif matematis menurut Andiyana, Maya, \& Hidayat (2018:239) adalah kemampuan berpikir yang bertujuan untuk menciptakan atau menemukan ide baru yang berbeda, tidak umum, orisinil yang membawa hasil yang pasti dan tepat. Sedangkan menurut Lestari \& Zanthy (2019:187 ) kemampuan berfikir kreatif matematis merupakan suatu kemampuan dalam pembelajaran untuk membangun ide atau 
gagasan dan menyelesaikan masalah matematika yang meliputi kelancaran, keluwesan, keaslian dan elaborasi. Sehingga dapat disimpulkan bahwa kemampuan berpikir kreatif matematis adalah kemampuan untuk menciptakan, menemukan, membangun ide atau gagasan baru (orisinil) dalam menyelesaikan masalah matematika yang meliputi kelancaran, keluwesan, keaslian dan elaborasi untuk tujuan hasil yang pasti dan tepat.

Kemampuan berpikir kreatif matematis sangatlah penting bagi siswa untuk mempersiapkan masa depan yang semakin maju dan penuh dengan tantangan. Kemampuan berpikir kreatif matematis tidak bisa muncul dengan sendirinya melainkan butuh suatu latihan. Dalam hal ini guru harus bisa melatih dan mengasah kemampuan berpikir kreatif siswa dengan pembelajaran yang memunculkan permasalahan-permasalahan sehari-hari. Matematika memberikan ruang kepada siswa untuk dapat menata kemampuan berpikir para siswa, bernalar, memecahkan masalah, berkomunikasi, mengaitkan materi matematika dengan keadaan sesungguhnya, serta mampu menggunakan dan memanfaatkan teknologi. Oleh karena itu berpikir kreatif matematis merupakan bagian keterampilan hidup yang sangat diperlukan siswa dalam menghadapi kemajuan IPTEKS yang semakin pesat serta tantangan, tuntutan dan persaingan global yang semakin pesat.

Berdasarkan hasil penelitian terdahulu mengatakan bahwa kemampuan berpikir kreatif matematis siswa sangatlah rendah, diantaranya : (1)Penelitian Lestari \& Zanthy(2019:187) mengatakan bahwa kemampuan berpikir kreatif matematis siswa SMK di Kota Cimahi pada materi geometri ruang sangat rendah dengan melihat rata-rata presentase sebesar 42,24\%. (2)Penelitian Rasnawati, Rahmawati, Akbar, \& Putra (2019:164) mengatakan bahwa kemampuan berfikir kreatif matematis siswa SMK di Kota Cimahi pada materi sistem persamaan linier dua variabel masih sangat rendah dengan rata-rata persentase dari semua indikator sebesar 39\%. (3) Penelitian Prianggono, Riyadi., \& Triyanto (2013) Siswa kelas X di SMK Negeri 1 Pacitan secara umum berada pada tingkatan siswa tidak kreatif dalam pemecahan dan pengajuan masalah matematika pada materi persamaan kuadrat. (4)Penelitian Hardiyanti (2016:57) terhadap siswa SMK Sore Tulung Agung dilihat dari tiga aspek saja yaitu aspek fleksibilitas, kefasihan, dan kebaharuannya termasuk siswa yang cukup kreatif pada materi barisan dan deret.

Berdasarkan wawancara peneliti pada beberapa guru matematika di SMK kota Pekanbaru mengatakan bahwa siswa SMK sulit untuk menjawab soal matematika HOTS karena mereka sudah terbiasa dengan soal matematika sesuai contoh guru dan diakui bahwa guru kurang memunculkan permasalahan-permasalahan sehari-hari sehingga mereka cukup mampu menjawab soal matematika yang diberikan dengan menguasai teknik-teknik yang diajarkan, namun mereka tidak bisa jika dituntut memecahkan masalah yang memerlukan cara-cara yang baru".

Oleh karena itu maka peneliti merasa tertarik untuk menganalisis kemampuan berpikir kreatif matematis siswa SMK di kota Pekanbaru pada materi barisan dan deret dengan 4 aspek yang menjadi indikator kreativitas yaitu Kelancaran (fluency), keluwesan (flexibility), Keaslian (originality) dan Elaborasi (elaboration). Penelitian ini bertujuan untuk mendeskripsikan kemampuan berpikir kreatif matematis siswa SMK di kota Pekanbaru pada materi barisan dan deret. 


\section{METODE PENELITIAN}

Jenis penelitian yang digunakan adalah penelitian deskriptif kualitatif. Subjek penelitian adalah 36 orang siswa kelas X TKJ 2 SMKN 2 Pekanbaru. Teknik pengumpulan data menggunakan tes uraian kemampuan berpikir kreatif matematis siswa pada materi barisan dan deret yang terdiri dari 4 soal uraian dengan setiap soal mengandung satu indikator kemampuan berpikir kreatif matematis siswa. Soal dipilih dari bank soal ujian nasional. Penelitian dilaksanakan pada semester ganjil tahun ajaran 2019-2020 tanggal 17 oktober 2019. Langkah - langkah analisis data:

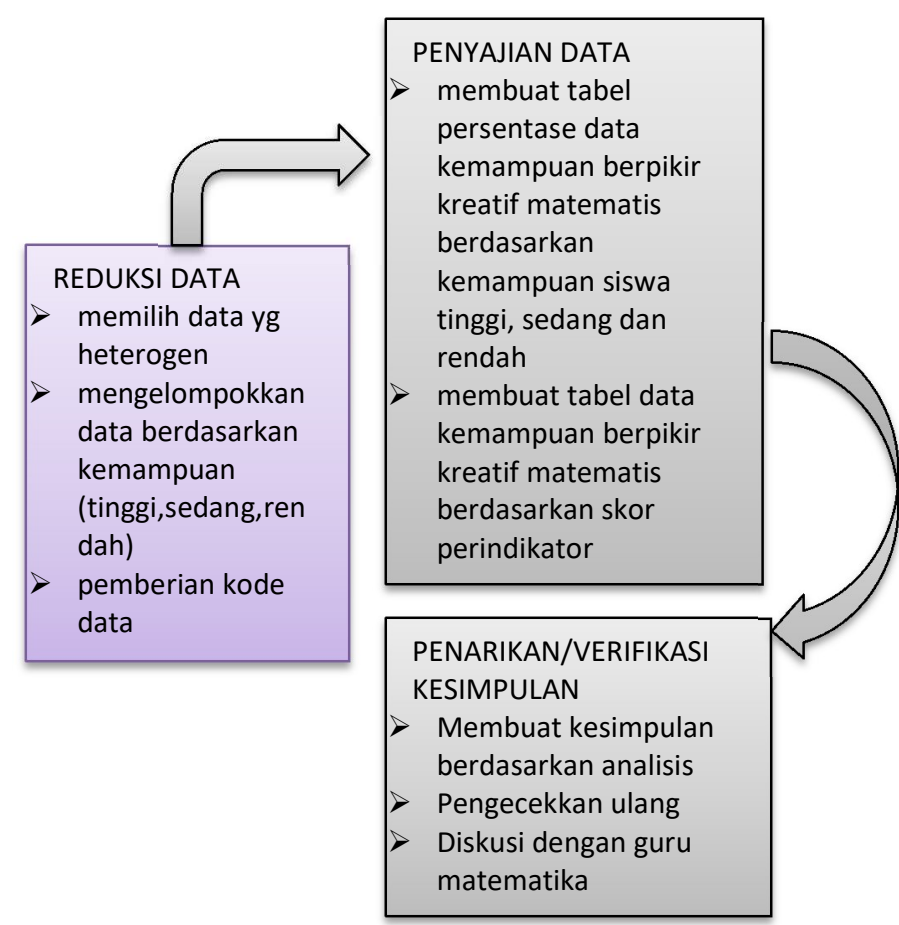

Gambar 1. Bagan Analisis Data

Pengkategorian tinggi atau rendahnya kemampuan berpikir kreatif berdasarkan tabel berikut :

Tabel 1. Kriteria Kemampuan Berpikir Kreatif

\begin{tabular}{|c|c|}
\hline Persentase (\%) & Kriteria \\
\hline $68-100$ & Kreatif \\
\hline $33-67$ & Cukup Kreatif \\
\hline $0-33$ & Kurang Kreatif \\
\hline
\end{tabular}

Putra, Akhdiyat, Setiany, \& Andiarani (2018)

\section{HASIL DAN PEMBAHASAN}

Data tes diperoleh dari hasil analisis jawaban siswa berdasarkan acuan pedoman penskoran kemampuan berpikir kreatif matematis Oktaviani(Rasnawati 2019:167). Pada penelitian ini meliputi Kelancaran (fluency), Keluwesan (flexibility), Keaslian (originality), Elaborasi (elaboration). 
Analisis Kemampuan Berpikir Kreatif Matematis Siswa Smk Pada Materi Barisan Dan

Deret Di Kota Pekanbaru

Indira Santi ${ }^{1}$, Maimunah ${ }^{2 *}$, Yenita Roza ${ }^{3}$

Tabel 2. Kemampuan berpikir kreatif matematis siswa berdasarkan tingkat kemampuan

\begin{tabular}{|c|c|c|c|c|c|}
\hline No & Indikator & Rendah & Sedang & Tinggi & Persentase \\
\hline 1 & Kelancaran (fluency) & 0 & 2 & 3 & $14 \%$ \\
\hline 2 & Keaslian(originality) & 0 & 2 & 1 & $8 \%$ \\
\hline 3 & Elaborasi(elaboration) & 3 & 5 & 6 & $39 \%$ \\
\hline 4 & Keluwesan(flexibility) & 0 & 0 & 0 & $0 \%$ \\
\hline
\end{tabular}

Tabel 2 memperlihat bahwa dari 36 siswa, pada indikator kelancaran (fluency) $14 \%$ siswa memperoleh skor tertinggi yaitu 3 siswa berkemampuan tinggi dan 2 siswa berkemampuan sedang. Pada indikator Keaslian (originality) $8 \%$ siswa memperoleh skor tertinggi yaitu 1 siswa berkemampuan tinggi dan 2 siswa berkemampuan sedang. Pada indikator Elaborasi(elaboration) $39 \%$ siswa memperoleh skor tertinggi yaitu 6 siswa berkemampuan tinggi, 5 siswa berkemampuan sedang dan 3 siswa berkemampuan rendah. Pada indikator Keluwesan(flexibility) $0 \%$ siswa memperoleh skor tertinggi. Maka disimpulkan bahwa kemampuan berpikir kreatif matematis siswa SMK di Pekanbaru berdasarkan tingkat kemampuan tinggi, sedang dan rendah adalah kurang kreatif.

Persentase kemampuan berpikir kreatif matematis siswa SMK berdasarkan skor perindikator

(1) Indikator Kelancaran (fluency) dengan persentase sebagai berikut :

Tabel 3. Indikator Kelancaran (fluency)

\begin{tabular}{|l|c|c|}
\hline \multicolumn{1}{|c|}{$\begin{array}{l}\text { Respon Siswa } \\
\text { Terhadap Soal }\end{array}$} & Skor & $\begin{array}{c}\text { Jumlah Siswa yang } \\
\text { Memperoleh Skor }\end{array}$ \\
\hline $\begin{array}{l}\text { Tidak memberikan jawaban atau memberikan sebuah ide } \\
\text { yang tidak relevan }\end{array}$ & 0 & 3 \\
\hline $\begin{array}{l}\text { Memberikan sebuah ide yang relevan tetapi } \\
\text { penyelesaiannya kurang jelas }\end{array}$ & 1 & 9 \\
\hline $\begin{array}{l}\text { Memberikan sebuah ide yang relevan penyelesainnya } \\
\text { lengkap dan jelas }\end{array}$ & 2 & 6 \\
\hline $\begin{array}{l}\text { Memberikan lebih dari satu ide yang relevan tetapi } \\
\text { penyelesaiannya kurang jelas }\end{array}$ & 3 & 5 \\
\hline $\begin{array}{l}\text { Memberikan lebih dari satu ide yang relevan } \\
\text { penyelesaiannya lengkap dan jelas }\end{array}$ & 4 & 80 \\
\hline \multicolumn{1}{|c|}{ Persentase } & $56 \%$ \\
\hline
\end{tabular}

Tabel 3 memperlihatkan bahwa pada indikator kelancaran (fluency) dari 36 siswa, jumlah siswa yang memperoleh skor 0 sebanyak 3 siswa, skor 1 sebanyak 9 siswa, skor 2 sebanyak 6 siswa, skor 3 sebanyak 13 siswa dan skor 4 sebanyak 5 siswa. Sehingga tabel 3 menunjukkan kemampuan berfikir indikator lancar (fluency) pada soal nomor 1 dengan persentase $56 \%$. 
(2) Indikator Keaslian (originality) dengan persentase sebagai berikut :

Tabel 4. Indikator Keaslian (originality)

\begin{tabular}{l|cc}
\hline \multicolumn{1}{c}{ Respon Siswa Terhadap Soal } & Skor & $\begin{array}{c}\text { Jumlah Siswa yang } \\
\text { Memperoleh Skor }\end{array}$ \\
\hline $\begin{array}{l}\text { Tidak memberikan jawaban atau memberikan jawaban } \\
\text { salah }\end{array}$ & 0 & 7 \\
\hline $\begin{array}{l}\text { Memberikan jawaban dengan cara sendiri tetapi tidak } \\
\text { dapat dipahami }\end{array}$ & 1 & 13 \\
\hline $\begin{array}{l}\text { Memberi jawaban dengan caranya sendiri proses } \\
\text { perhitungan dapat dipahami hanya saja informasi } \\
\text { kurang jelas }\end{array}$ & 2 & 3 \\
\hline $\begin{array}{l}\text { Memberi jawaban dengan caranya sendiri } \\
\text { perhitungannya benar tetapi informasi kurang jelas }\end{array}$ & 3 & 3 \\
\hline $\begin{array}{l}\text { Memberi jawaban dengan caranya sendiri perhitungan } \\
\text { dan hasilnya benar }\end{array}$ & 4 & 54 \\
\hline Jumlah & $38 \%$ \\
\hline
\end{tabular}

Tabel 4 memperlihat bahwa pada indikator keaslian (originality) dari 36 siswa, jumlah siswa yang memperoleh skor 0 sebanyak 7 siswa, Skor 1 sebanyak 13 siswa, Skor 2 sebanyak 10, skor 3 sebanyak 3 siswa dan skor 4 sebanyak 3 siswa. Sehingga tabel 3 menunjukkan kemampuan berfikir indikator keaslian (originality) pada soal nomor 2 dengan persentase $38 \%$.

(3) Indikator Elaborasi (elaboration) dengan persentase sebagai berikut :

Tabel 5. Indikator Elaborasi (elaboration)

\begin{tabular}{|c|c|c|}
\hline Respon Siswa Terhadap Soal & Skor & $\begin{array}{l}\text { Jumlah Siswa yang } \\
\text { Memperoleh Skor }\end{array}$ \\
\hline $\begin{array}{l}\text { Tidak memberikan jawaban atau memberikan jawaban } \\
\text { yang salah }\end{array}$ & 0 & 12 \\
\hline $\begin{array}{l}\text { Terdapat kesalahan dalam jawaban dan tidak disertai } \\
\text { perincian }\end{array}$ & 1 & 10 \\
\hline $\begin{array}{l}\text { Terdapat kesalahan dalam jawaban tetapi disertai } \\
\text { perincian yang kurang detail }\end{array}$ & 2 & 0 \\
\hline $\begin{array}{l}\text { Terdapat kesalahan dalam jawaban tetapi disertai } \\
\text { perincian yang rinci }\end{array}$ & 3 & 0 \\
\hline Memberikan jawaban yang benar dan rinci & 4 & 14 \\
\hline Jumlah & & 66 \\
\hline Persentase & & $46 \%$ \\
\hline
\end{tabular}

Tabel 5 memperlihatkan bahwa pada indikator Elaborasi (elaboration) dari 36 siswa, jumlah siswa yang memperoleh skor 0 sebanyak 12 siswa, Skor 1 sebanyak 10 siswa, Skor 2 dan 3 sebanyak 0 siswa dan skor 4 sebanyak 14 siswa. Sehingga tabel 4 menunjukkan kemampuan berfikir Indikator Elaborasi (elaboration) pada soal nomor 3 dengan persentase $46 \%$. 
(4) Indikator Keluwesan (flexibility)dengan persentase sebagai berikut :

Tabel.6 Indikator Keluwesan (flexibility)

\begin{tabular}{lcc}
\hline \multicolumn{1}{c}{ Respon Siswa Terhadap Soal } & Skor & $\begin{array}{c}\text { Jumlah Siswa yang } \\
\text { Memperoleh Skor }\end{array}$ \\
\hline $\begin{array}{l}\text { Tidak memberi jawaban dengan satu cara atau lebih } \\
\text { tetapi semua salah }\end{array}$ & 0 & 2 \\
\hline $\begin{array}{l}\text { Memberikan jawaban satu cara atau lebih tetapi jawaban } \\
\text { salah }\end{array}$ & 1 & 6 \\
\hline $\begin{array}{l}\text { Memberikan jawaban satu cara atau lebih, proses } \\
\text { perhitungan dan hasilnya benar }\end{array}$ & 2 & 0 \\
\hline $\begin{array}{l}\text { Memberikan jawaban lebih dari satu cara (beragam) } \\
\text { tetapi hasilnya ada yang salah karena terdapat kekeliruan } \\
\text { karena proses perhitungan }\end{array}$ & 3 & 0 \\
\hline $\begin{array}{l}\text { Memberikan jawaban lebih dari satu cara (beragam), } \\
\text { proses perhitungan dan hasilnya benar }\end{array}$ & 4 & 40 \\
\hline \multicolumn{1}{c}{ Jumlah } \\
\hline
\end{tabular}

Tabel 6 memperlihatkan bahwa pada indikator Keluwesan (flexibility) dari 36 siswa jumlah siswa yang memperoleh skor 0 sebanyak 2 siswa, Skor 1 sebanyak 28 siswa, Skor 2 sebanyak 6 siswa, skor 3 dan skor 4 sebanyak 0 siswa. Sehingga tabel 5 menunjukkan kemampuan berfikir indikator keluwesan (flexibility) pada soal nomor 4 dengan persentase $28 \%$.

Persentase yang diperoleh siswa dari semua indikator kemampuan berpikir kreatif matematis semua berada di bawah $60 \%$, yaitu indikator kelancaran (fluency) $56 \%$ indikator Keaslian (originality) $38 \%$ indikator Elaborasi (elaboration) adalah $46 \%$ dan indikator Keluwesan (flexibility) adalah $28 \%$, sehingga dapat disimpulkan bahwa siswa kelas X TKJ 2 termasuk siswa yang cukup kreatif.

\section{Soal no 1}

Pabrik pada bulan pertama memproduksi 120 pasang sepatu, setiap bulannya hasil produksi mengalami pertambahan 30 pasang sepatu. Jumlah pasang sepatu di produksi pabrik pada tahun pertama adalah ....

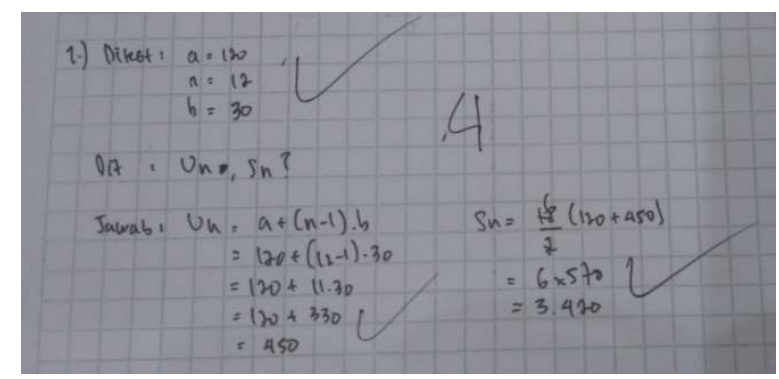

Gambar 1. jawaban siswa berkemampuan tinggi pada soal no 1

Gambar 1 memperlihatkan bahwa siswa telah memberikan lebih dari satu ide yang relevan serta penyelesaiannya lengkap dan jelas. Pada indikator kelancaran(fluency) ini 
rata-rata persentase siswa mencapai $56 \%$ menunjukkan sebagian siswa mampu menjawab pertanyaan dengan benar dan lancar.
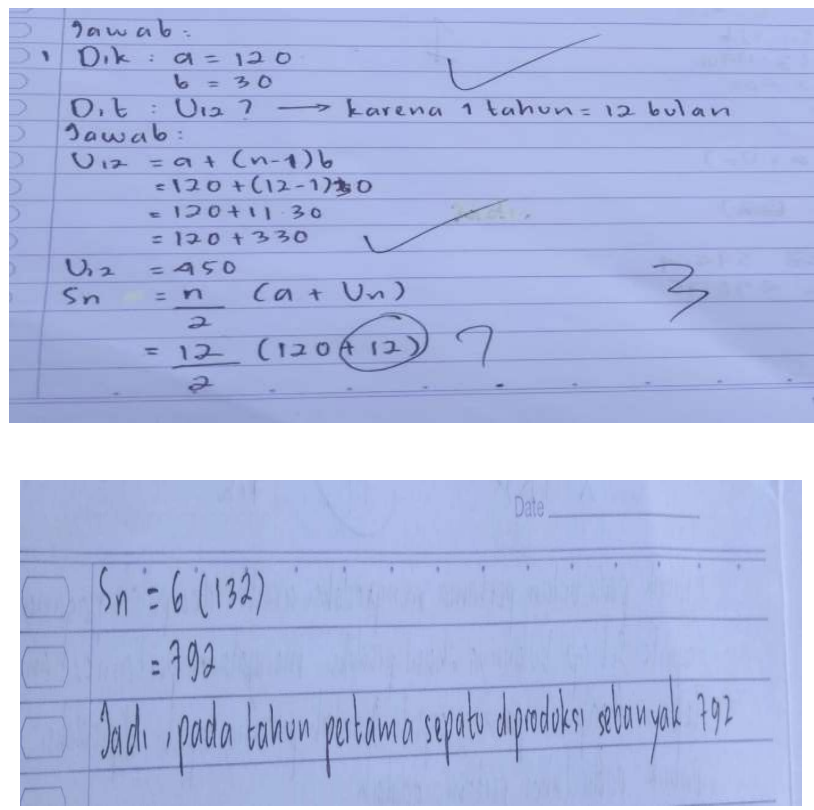

Gambar 2. Jawaban siswa berkemampuan sedang pada soal no 1

Gambar 2 memperlihatkan bahwa siswa telah memberikan lebih dari satu ide yang relevan tetapi penyelesaiannya kurang jelas. Pada indikator kelancaran (fluency) kemampuan berpikir kreatif matematis siswa rata-rata 56\%. menunjukkan sebagian siswa telah mampu berpikir lancar.

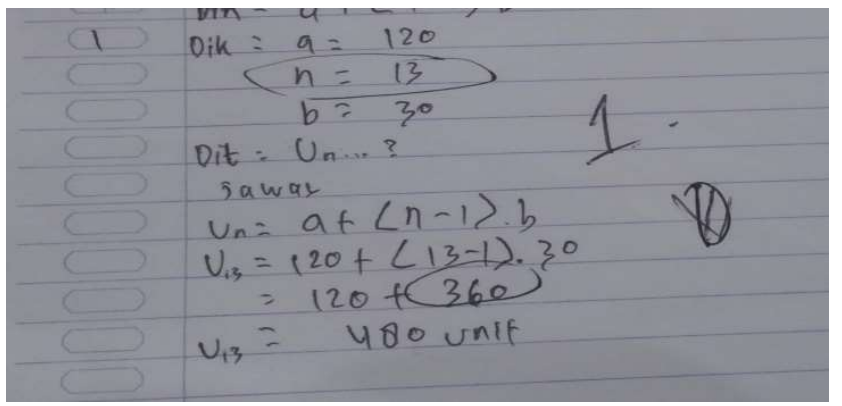

Gambar 3. Jawaban siswa berkemampuan rendah

Gambar 3 memperlihatkan bahwa siswa telah memberikan satu ide yang relevan tetapi penyelesaiannya kurang jelas. Pada indikator kelancaran (fluency) kemampuan berpikir kreatif matematis siswa rata-rata 56\% . menunjukkan sebagian siswa telah mampu berpikir lancar.

\section{Soal no 2}

Suatu perusahaan air minum pada bulan ke-2 dapat menjual 6.400 botol minuman. Sedangkan pada bulan ke-12 dapat menjual 10.400 botol minuman. Peningkatan penjualan setiap bulannya memenuhi barisan aritmatika. Maka jumlah penjualan minuman satu setengah tahun pertama adalah ... 


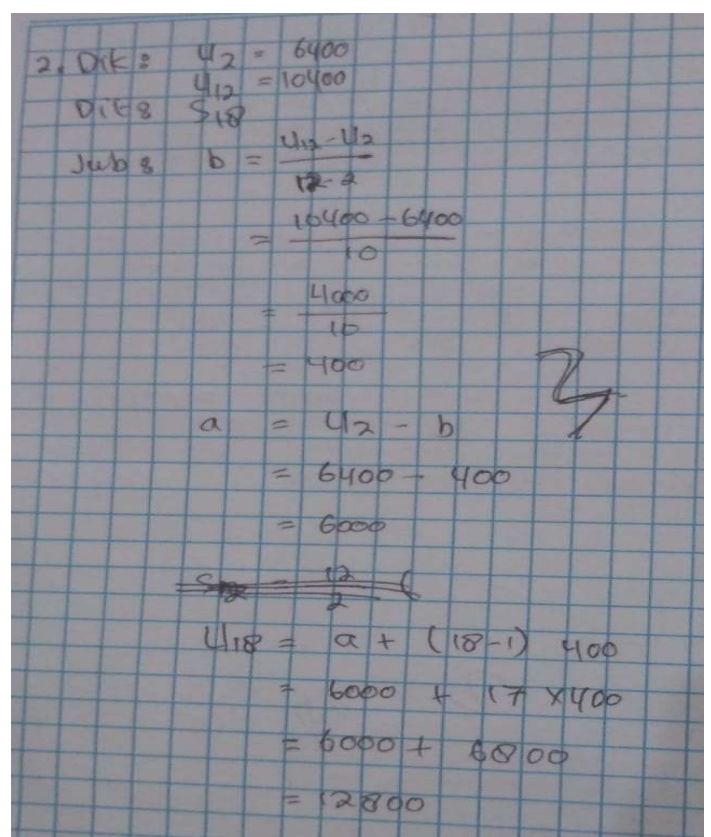

Gambar 4 jawaban siswa berkemampuan tinggi pada soal no 2

Gambar 4 memperlihatkan bahwa siswa telah memberi jawaban dengan caranya sendiri perhitungannya benar tetapi informasi kurang jelas Pada indikator keaslian (originality) ini rata-rata persentase siswa mencapai $38 \%$ menunjukkan siswa belum mampu berpikir originality.

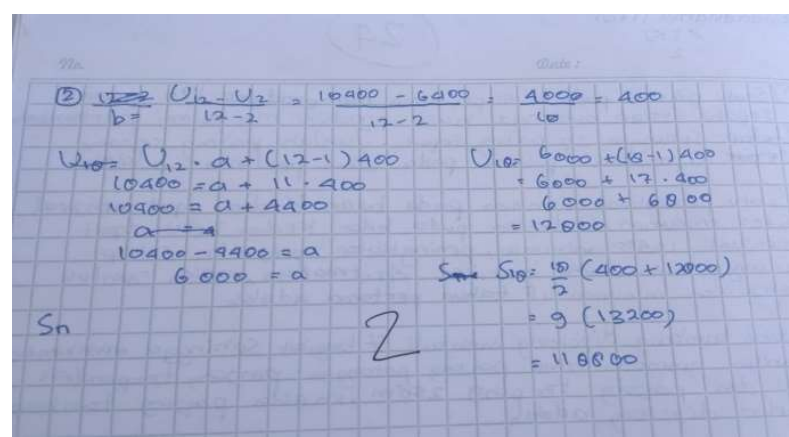

Gambar 5. jawaban siswa berkemampuan sedang pada soal no 2

Gambar 5 memperlihatkan bahwa siswa telah memberi jawaban dengan caranya sendiri proses perhitungan dapat dipahami hanya saja informasi kurang jelas. Pada indikator keaslian (originality) ini persentase siswa mencapai 38\% menunjukkan siswa belum mampu berpikir originality.

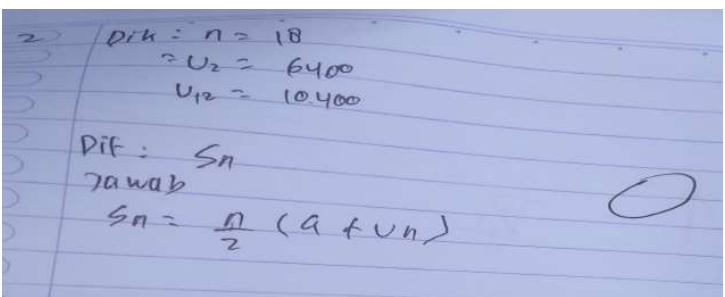

Gambar 6. jawaban siswa berkemampuan rendah pada soal no 2 
Gambar 6 memperlihatkan bahwa siswa tidak memberikan jawaban. Pada indikator keaslian (originality) ini rata-rata persentase siswa mencapai $38 \%$ menunjukkan siswa belum mampu berpikir originality.

\section{Soal no 3}

Suatu tambang dipotong menjadi 7 bagian, sehingga membentuk barisan geometri. Jika panjang potongan tambang terpendek $4 \mathrm{~m}$ dan panjang potongan tambang terpanjang 256 $\mathrm{m}$, maka panjang tambang sebelum dipotong adalah ...

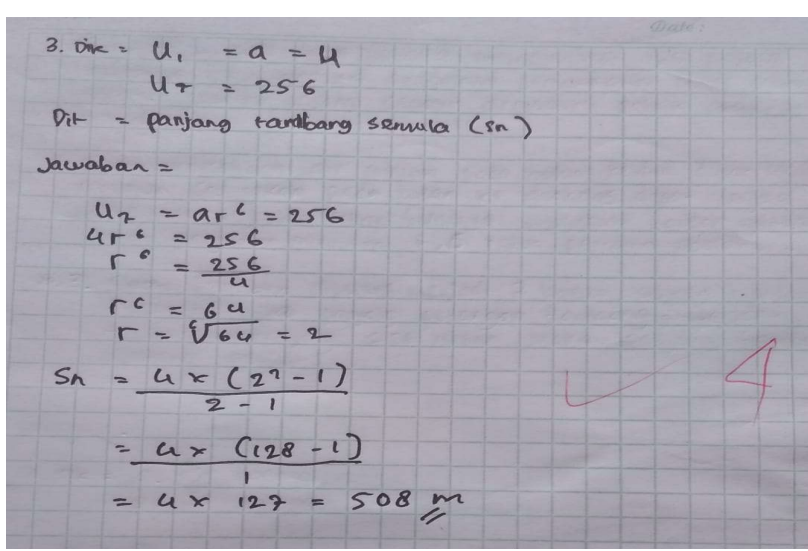

Gambar 7. Jawaban siswa berkemampuan tinggi pada soal no 3

Gambar 7 memperlihatkan bahwa siswa telah memberikan jawaban yang benar dan rinci. Pada indikator Elaborasi (elaboration) ini rata-rata persentase siswa mencapai $46 \%$ menunjukkan sebagian siswa belum mampu berpikir secara rinci.

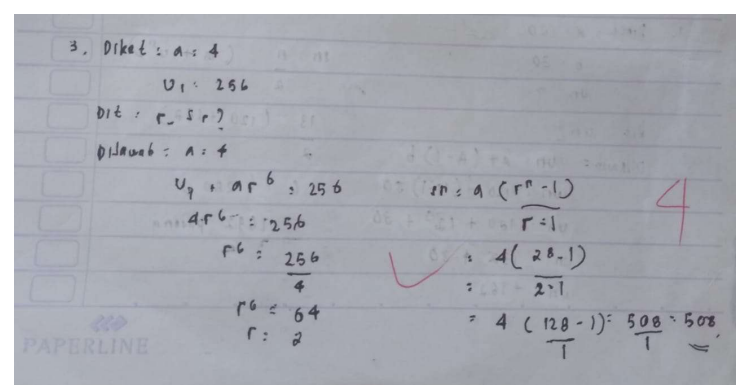

Gambar 8 jawaban siswa berkemampuan sedang pada soal no 3

Gambar.8 memperlihatkan bahwa siswa telah memberikan jawaban yang benar dan rinci. Pada indikator Elaborasi (elaboration) ini rata-rata persentase siswa mencapai $46 \%$ menunjukkan sebagian siswa belum mampu berpikir secara rinci.

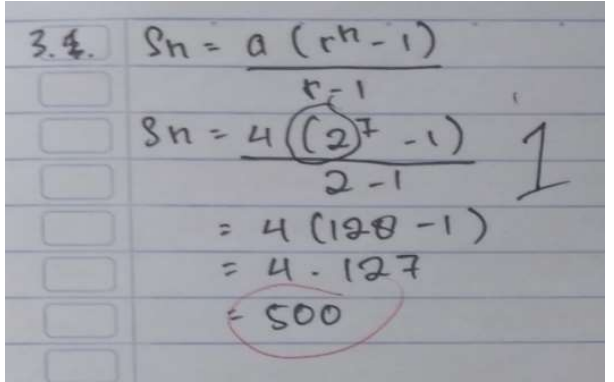

Gambar 9. jawaban siswa berkemampuan rendah pada soal no 3 
Gambar 9 memperlihatkan bahwa Terdapat kesalahan dalam jawaban dan tidak disertai perincian. Pada indikator Elaborasi (elaboration) ini rata-rata persentase siswa mencapai $46 \%$ menunjukkan sebagian siswa belum mampu berpikir secara rinci.

\section{Soal no 4}

Pak Budi membeli satu unit sepeda motor dengan harga Rp 18.000.000,00 pada awal tahun 2019, ia merencanakan mengganti kendaraannya setelah digunakan selama lima tahun. Ia memperkirakan terjadinya penyusutan terhadap nilai jual kendaraan sebesar 10 $\%$ pertahun. Nilai jual setelah kendaraan digunakan selama lima tahun adalah ...(selesaikan dengan 2 cara)

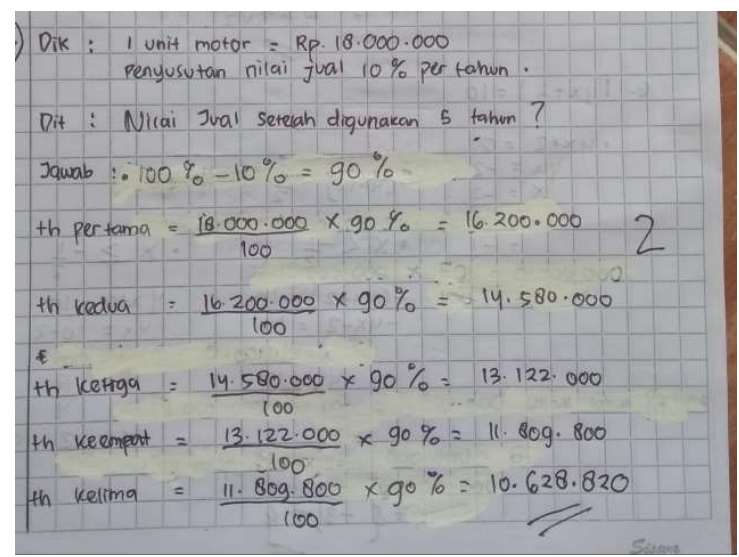

Gambar 10 jawaban siswa berkemampuan tinggi pada soal no 4

Gambar 10 memperlihatkan bahwa siswa memberikan jawaban satu cara tetapi proses perhitungan dan hasil benar. Pada indikator Keluwesan (flexibility) kemampuan berpikir kreatif matematis siswa rata-rata $28 \%$. Menunjukkan bahwa siswa belum mampu berpikir kreatif jika diukur dari indikator Keluwesan (flexibility).

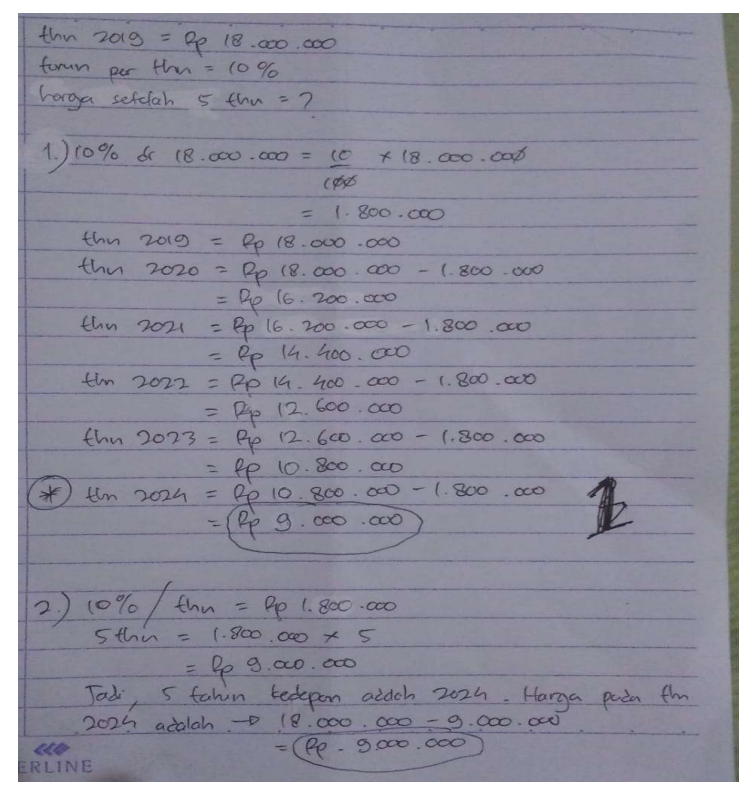

Gambar 11 jawaban siswa berkemampuan sedang pada soal no 4 
Gambar 11 memperlihatkan bahwa siswa memberikan jawaban dengan dua cara tetapi jawaban salah, Pada indikator Keluwesan (flexibility) kemampuan berpikir kreatif matematis siswa rata-rata $28 \%$. Menunjukkan bahwa siswa belum mampu berpikir kreatif jika diukur dari indikator Keluwesan (flexibility).

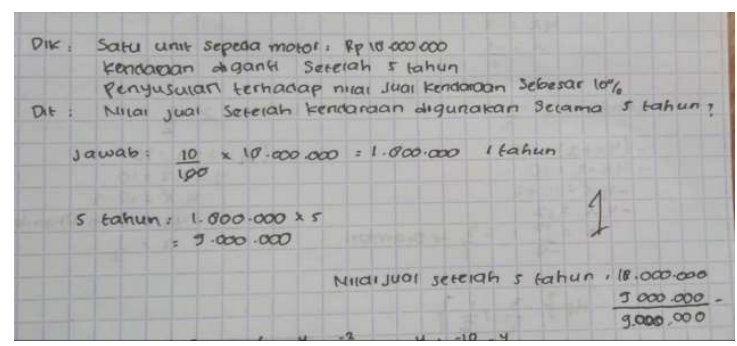

Gambar 12 jawaban siswa berkemampuan rendah pada soal no 4

Gambar.12 memperlihatkan bahwa siswa memberikan jawaban dengan dua cara tetapi jawaban salah, Pada indikator Keluwesan (flexibility) kemampuan berpikir kreatif matematis siswa rata-rata $28 \%$. Menunjukkan bahwa siswa belum mampu berpikir kreatif jika diukur dari indikator Keluwesan (flexibility).

\section{KESIMPULAN}

Kemampuan berfikir kreatif matematis siswa SMK di Kota Pekanbaru pada materi Barisan dan deret menunjukkan cukup kreatif dengan rata-rata persentase dari semua indikator sebesar $42 \%$. Untuk indikator kelancaran (fluency) $56 \%$, indikator Keaslian (originality) $38 \%$, indikator Elaborasi (elaboration) $46 \%$ dan indikator Keluwesan (flexibility) adalah $28 \%$. Kelancaran (fluency) merupakan persentase tertinggi dan keluwesan (flexibility) merupakan persentase paling rendah. Untuk meningkatkan kemampuan berpikir kreatif matemtis siswa, hendaknya guru lebih membiasakan mereka mengerjakan soal-soal yang memuat indikator berpikir kreatif matematis. Perlu juga diadakan penelitian lanjutan mengenai pembelajaran apa yang paling tepat untuk meningkatkan kemampuan berpikir kreatif matematis siswa.

\section{REFERENSI}

Andiyana, M. A., Maya, R., \& Hidayat, W. 2018. "Analisis kemampuan berpikir kreatif matematis siswa smp pada materi bangun ruang". Journal Pebelajaran Matematika Inovatif, 1(3), 239-248. https://doi.org/10.22460/jpmi.v1i3.239-248

Hardiyanti, A. 2016. "Analisis kreativitas siswa dalam menyelesaikan soal matematika pada materi barisan dan deret". Konferensi Nasional Penelitian Matematika Dan Pembelajarannya)KNPMP I).

Lestari, N., \& Zanthy, L. S. 2019. "Analisis Kemampuan Berpikir Kreatif Matematis Siswa Smk Di Kota Cimahi Pada Materi Geomertri Ruang". JPMI (Jurnal Pembelajaran Matematika Inovatif), 2(4), 187-196.

Mulyaningsih, T., \& Ratu, N. 2018. "Analisis Kemampuan Berpikir Kreatif Siswa SMP dalam Memecahkan Masalah Matematika pada Materi Pola Barisan Bilangan". JIPMat. https://doi.org/10.26877/jipmat.v3i1.2187 
Analisis Kemampuan Berpikir Kreatif Matematis Siswa Smk Pada Materi Barisan Dan Deret Di Kota Pekanbaru

Indira Santi ${ }^{1}$, Maimunah ${ }^{2 *}$, Yenita Roza ${ }^{3}$

Oktaviani, Y. 2013."Meningkatkan Kemampuan Berfikir Kreatif Matematik Siswa SMA yang Pembelajarannya Menggunakan Metode Tutor Sebaya". Skripsi Jurusan Pendidikan STKIP Siliwangi. Bandung: Tidak diterbitkan.

Prianggono, A., Riyadi., \& Triyanto. 2013. (Mari wes)"Analisis Proses Berpikir Kreatif Siswa Sekolah Menengah Kejuruan (SMK) Dalam Pemecahan Dan Pengajuan Masalah Matematika Pada MAteri Persamaan Kuadrat". Jurnal Pembelajaran Matematika.

Putra, H. D., Akhdiyat, A. M., Setiany, E. P., \& Andiarani, M. 2018. "Kemampuan Berpikir Kreatif Matematik Siswa SMP di Cimahi". Kreano, 9(1), 47-53.

Rasnawati, A., Rahmawati, W., Akbar, P., \& Putra, H. D. 2019. "Smk Pada Materi Sistem Persamaan Linier Dua Variabel". Jurnal Cendikia: Jurnal Pendidikan Matematika, 3(1), 164-177. 